\title{
SM905, an artemisinin derivative, inhibited NO and pro-inflammatory cytokine production by suppressing MAPK and NF-KB pathways in RAW 264.7 macrophages
}

\author{
Jun-xia WANG ${ }^{1}$, Li-fei HOU ${ }^{1}$, Yang YANG ${ }^{3}$, Wei TANG ${ }^{1}$, Ying $\mathrm{LI}^{2}$, Jian-ping ZUO ${ }^{1,3, *}$ \\ ${ }^{1}$ Laboratory of Immunopharmacology; ${ }^{2}$ Department of Synthetic Chemistry, State Key Laboratory of Drug Research, Shanghai Institute \\ of Materia Medica, Chinese Academy of Sciences, Shanghai 201203, China; ${ }^{3}$ Laboratory of Immunology and Virology, Shanghai Uni- \\ versity of Traditional Chinese Medicine, Shanghai 201203, China
}

\begin{abstract}
Aim: To elucidate the anti-inflammatory potentials and underlying mechanisms of SM905, a novel artemisinin derivative, in lipopolysaccharide (LPS)-stimulated murine macrophage RAW 264.7 cells.

Methods: Nitric oxide (NO) generation, cytokine production, and the protein expression levels of inducible nitric-oxide synthase (iNOS) and cyclooxygenase-2 (COX-2) were examined using a Griess assay, an enzyme-linked immunosorbent assay (ELISA) and a Western blotting assay, respectively. The mRNA expression was measured using real-time PCR. The phosphorylation of extracellular signalregulated kinase1/2 (ERK1/2), p38, c-jun N-terminal kinase (JNK), and the degradation of IkB $\alpha$ were assessed by Western blotting analysis. The nuclear translocation of nuclear factor-KB (NF-KB) was observed using confocal microscopy.

Results: Pretreatment with SM905 (0, 0.1, 1, and $10 \mu \mathrm{mol} / \mathrm{L})$ suppressed LPS-induced NO, TNF- $\alpha$, IL-1 $\beta$, and IL-6 production, and decreased both protein and mRNA levels of iNOS and COX-2. The mRNA expression of LPS receptor Toll-like receptor 4 (TLR4) and myeloid differentiation protein-2 (MD-2) was not changed, while LPS-induced CD14 expression was slightly reduced after SM905 treatment. SM905 markedly decreased the activation of ERK1/2, p38 and JNK suppressed the degradation of IkB $\alpha$, but did not modify the expression of interferon regulatory factor-1 (IRF-1), signal transducer and activator of transcription 1 (STAT1) or interferon-inducible protein-10 (IP-10). By using confocal microscopy, we further observed that NF-kB was correspondingly inhibited in SM905-treated cells. Conclusion: SM905 inhibited NO and pro-inflammatory cytokine production in LPS-stimulated RAW 264.7 cells and these effects are at least partially mediated through suppression of the MAPK and NF-kB signaling pathways.
\end{abstract}

Keywords: artemisinin; SM905; NO; iNOS; inflammation; MAPK; NF-kB; cyclooxygenase 2; TLR4 receptor

Acta Pharmacologica Sinica (2009) 30: 1428-1435; doi: 10.1038/aps.2009.138

\section{Introduction}

The secretion of inflammatory mediators by macrophages is involved in both the innate and adaptive immune responses of many human diseases, such as rheumatoid arthritis $(\mathrm{RA})^{[1]}$. LPS, a component of the cell wall of gram-negative bacteria, is known to activate a number of cellular signals in macrophages ${ }^{[2]}$. Once activated, macrophages produce large amounts of nitric oxide (NO) and pro-inflammatory cytokines (tumor necrosis factor (TNF)- $\alpha$, IL-1 $\beta$ and IL-6). Both the inflammatory signaling pathways and pro-inflammatory mediators provide various effective targets for the generation

* To whom correspondence should be addressed.

E-mail jpzuo@mail.shcnc.ac.cn

Received 2009-06-09 Accepted 2009-08-07 of new anti-inflammatory agents ${ }^{[3]}$.

LPS binding with its receptor is the initial step of LPS signaling. The functional integrity of the LPS receptor is composed of three proteins: CD14, Toll-like receptor 4 (TLR4), and myeloid differentiation protein-2 (MD-2). LPS activates macrophages through CD14 and the TLR4/MD-2 complex on the cell surface ${ }^{[4]}$. CD14 and TLR4/MD-2 are essential for conferring cellular responsiveness to LPS. Mice that lack CD14 expression are resistant to death after injections of LPS and produce only a very small elevation of serum TNF-a ${ }^{[5]}$. Similarly, down-regulation of TLR4/MD-2 expression also induces LPS tolerance ${ }^{[6]}$.

After recognition of the LPS/CD14 complex, TLR4/MD-2 activates several downstream signal pathways, including mitogen-activated protein kinases (MAPKs) and nuclear factor- $\mathrm{KB}$ 
(NF-kB), through adaptor proteins of the myeloid differentiation factor 88 (MyD88) family ${ }^{[7,8]}$. In addition, TLR4/MD-2 utilizes adaptors independently of MyD88 to induce the expression of interferon (IFN)-inducible genes, such as interferoninducible protein-10 (IP-10), via the members of the interferon regulatory factor (IRF) family ${ }^{[9]}$. Both the MyD88-dependent and MyD88-independent signaling pathways are important for the macrophage response to LPS ${ }^{[10]}$. Upon activation, MAPK and NF-kB pathways coordinate the upregulation of pro-inflammatory mediator gene expression ${ }^{[11]}$. MAPKs are a highly conserved family of protein serine/threonine kinases with three major groups: extracellular signal-regulated kinase (ERK), p38 and c-jun N-terminal kinase (JNK) MAPK ${ }^{[12]}$, all of which can be strongly activated by LPS; they participate in inducing TNF- $\alpha$, IL-1 $\beta$, and IL-6 production at transcription, translation, or both levels, in human and murine macrophages $^{[13]}$. NF-kB is constitutively present as homo- or heterodimers and binds to inhibitory factor $\kappa \mathrm{B}(\mathrm{I} \kappa \mathrm{B})$ proteins in the cytoplasm of resting cells. LPS stimulation leads to phosphorylation, ubiquitination, and degradation of one of the isoforms of $\mathrm{I} \mathrm{B}$, IкBa, with associated release and nuclear translocation of $\mathrm{NF}-\mathrm{KB}^{[14]}$. NF- $\mathrm{kB}$ transcription factor functionally and physically interacts with members of other transcription factor families and cooperatively regulates the transcriptional activation of many LPS-inducible genes involved in immune and inflammatory responses, such as pro-inflammatory cytokines (TNF-a, IL-1 $\beta$, and IL-6), inducible nitric-oxide synthase (iNOS), and cyclooxygenase-2 (COX-2) ${ }^{[2,14]}$.

For iNOS, IRF-1 is another transcription factor having the ability to regulate its gene transcription synergistically with NF-кB. The promoter of iNOS contains both NF-kB and IRF-1 binding sites ${ }^{[15]}$. Typically, IRF-1 is not expressed or is undetectable, and LPS stimulation induces a prominent gene expression of IRF-1 ${ }^{[15,16]}$. LPS is also known to induce the expression of signal transducer and activator of transcription 1 (STAT1 $)^{[17]}$, which is essential for the optimal induction of LPSstimulated IRF-1 gene expression. In macrophages prepared from STAT1-deficient mice, mRNA expression of IRF-1, IP-10, and iNOS in response to LPS was severely impaired ${ }^{[18]}$.

Natural products have proven to be a valuable source for new therapeutic drugs. The antimalarial drug artemisinin is isolated from the Chinese traditional herb Artemisia annua L. In addition to their antimalarial activity, artemisinin and its derivatives also exhibit potent immunosuppressive activities $^{[19-22]}$. With the goal of developing immunosuppressive agents from artemisinin, we synthesized a series of new compounds from artemisinin ${ }^{[23-25]}$. Recently, SM905, a novel water-soluble artemisinin derivative, was identified with promising immunosuppressive activity both in vitro and in vivo ${ }^{[26]}$. In a collagen-induced arthritis model, SM905 strongly inhibited both antigen-specific $\mathrm{T}$ cell response and inflammatory response in arthritic mice ${ }^{[27]}$.

The present study aims to further elucidate the anti-inflammatory potentials and underlying mechanisms of SM905 in LPS-stimulated murine macrophage RAW 264.7 cells.

\section{Materials and methods}

\section{Chemicals and Reagents}

SM905, (1-(12 $\beta$-Dihydroartemisinoxy)-2-hydroxy-3-tertbutylaminopropane maleate; $\mathrm{C}_{26} \mathrm{H}_{43} \mathrm{NO}_{10} ; \mathrm{MW}=530 ; 99 \%$ purity), was synthesized and provided by the Laboratory of Synthetic Chemistry, Shanghai Institute of Materia Medica. Before use, SM905 was dissolved in PBS as a stock solution, and stored at $-20{ }^{\circ} \mathrm{C}$. LPS, sulfanilamide, N-[naphthyl]ethylene diamine dihydrochloride and polyclonal antibody of $\beta$-actin were purchased from Sigma-Aldrich (St Louis, MO, USA). RPMI 1640 medium was purchased from Invitrogen (Carlsbad, CA, USA). FBS was purchased from Hyclone Laboratories (Logan, UT, USA). TNF- $\alpha$, IL-1 $\beta$, and IL-6 ELISA kits were from BD Biosciences Pharmingen (San Diego, CA, USA). Polyclonal antibodies of iNOS, COX-2, and NF-kB/p65 were purchased from Santa Cruz Biotechnology (Santa Cruz, CA, USA). Polyclonal antibodies of phospho-ERK, phospho-p38, phospho-JNK, and IкBa were purchased from Cell Signal Technology (Beverly, MA, USA).

\section{Cell cultures}

RAW 264.7 cells (American Type Culture Collection, Manassas, VA, USA), a murine macrophage cell line, were grown in Dulbecco's modified Eagle's medium containing $10 \%$ fetal bovine serum (FBS), $2 \mathrm{mmol} / \mathrm{L}$ L-glutamine, $100 \mathrm{U} / \mathrm{mL}$ penicillin, and $10 \mu \mathrm{g} / \mathrm{mL}$ streptomycin. They were maintained at $37^{\circ} \mathrm{C}$ in a humidified atmosphere of $5 \% \mathrm{CO}_{2}$.

\section{NO production and quantification}

RAW 264.7 cells $\left(5 \times 10^{5} / \mathrm{mL}\right)$ were pretreated with SM905 (0, $0.1,1$, and $10 \mu \mathrm{mol} / \mathrm{L}$ ) for $1 \mathrm{~h}$ before stimulation with $1 \mu \mathrm{g} / \mathrm{mL}$ LPS for $20 \mathrm{~h}$. Nitrite concentration, a measure of NO production, was assayed by a standard Griess reaction adapted to microplates as described previously ${ }^{[28]}$. In brief, $100 \mu \mathrm{L}$ of culture supernatant was mixed with an equal volume of Griess reagent ( $1 \%$ sulfanilamide and $0.1 \% \mathrm{~N}$-[naphthyl]ethylene diamine dihydrochloride in $2.5 \% \mathrm{H}_{3} \mathrm{PO}_{4}$ ) at room temperature for $10 \mathrm{~min}$. Absorbance was measured at $540 \mathrm{~nm}$ in a microplate reader (SpectraMax 190, Molecular Devices Corporation, Sunnyvale, CA, USA). Nitrite concentration was calculated from a $\mathrm{NaNO}_{2}$ standard curve.

\section{Measurement of cytokines}

Culture supernatants from the NO production assay in RAW 264.7 cells were collected. Pro-inflammatory cytokine TNF-a, IL-1 $\beta$, and IL-6 were measured using enzyme-linked immunosorbent assay (ELISA) kits and carried out according to the manufacturer's instructions.

\section{Real-time PCR analysis}

RAW 264.7 cells $\left(2 \times 10^{6} / \mathrm{mL}\right)$ were pretreated with SM905 $(0,0.1,1$, and $10 \mu \mathrm{mol} / \mathrm{L})$ for $1 \mathrm{~h}$ before stimulation with 1 $\mu \mathrm{g} / \mathrm{mL}$ LPS for $3 \mathrm{~h}$. Total RNA was isolated using Trizol reagent (Invitrogen, Carlsbad, CA, USA), reverse transcribed, and polymerase chain reaction amplified using specific prim- 
ers (Table 1). Relative quantitation with real-time PCR was performed with SYBR Green PCR Reagents (Qiagen, Valencia, CA, USA) and a Continuous Fluorescence Detection System (MJ Research, USA), according to the manufacturer's instructions as previously described ${ }^{[26]}$. The relative gene expression was normalized to hypoxanthineguanine phosphoribosyltransferase (HPRT) for each sample.

Table 1. Nucleotide sequences of the primers used for real-time PCR.

\begin{tabular}{|c|c|c|}
\hline Gene & & Sequence \\
\hline \multirow[t]{2}{*}{ iNOS } & $\mathrm{F}$ & 5'-AAGTCAAATCCTACCAAAGTGA-3' \\
\hline & $\mathrm{R}$ & 5'-CCATAATACTGGTTGATGAACT-3' \\
\hline \multirow[t]{2}{*}{$\operatorname{cox}-2$} & $\mathrm{~F}$ & 5'-GGGTGTGAAGGGAAATAAGG-3' \\
\hline & $\mathrm{R}$ & 5'-TCTCCACCAATGACCTGAT-3' \\
\hline \multirow[t]{2}{*}{ CD14 } & $\mathrm{F}$ & 5'-CCACCGCTGTAAAGGAAA-3' \\
\hline & $\mathrm{R}$ & 5'-CAGGGCTCCGAATAGAATC-3' \\
\hline \multirow[t]{2}{*}{ TLR4 } & $\mathrm{F}$ & 5'-GCAGAAAATGCCAGGATGA-3' \\
\hline & $\mathrm{R}$ & 5'-TGTTTCAATTTCACACCTGGA -3' \\
\hline \multirow[t]{2}{*}{ MD-2 } & $\mathrm{F}$ & 5'-ATTGGGTCTGCAACTCATCC-3' \\
\hline & $\mathrm{R}$ & 5'-TCATCAGATCCTCGGCAAAT-3' \\
\hline \multirow[t]{2}{*}{ IRF-1 } & $\mathrm{F}$ & 5'-GCCGAAGACCTTATGAAGC-3' \\
\hline & $\mathrm{R}$ & 5'-CCCACAGGAGTCTAGCTTTT-3' \\
\hline \multirow[t]{2}{*}{ STAT1 } & $\mathrm{F}$ & 5'-GCAAGCGTAATCTCCAGGA-3' \\
\hline & $\mathrm{R}$ & 5'-GGCTTCACCTTCTCTGTTCT-3' \\
\hline \multirow[t]{2}{*}{ IP-10 } & $\mathrm{F}$ & 5'-ATCCCGAGCCAACCTT-3' \\
\hline & $\mathrm{R}$ & 5'-AGGAGCCCTTTTAGACCTT-3' \\
\hline \multirow[t]{2}{*}{ HPRT } & $\mathrm{F}$ & 5'-GTTGGATACAGGCCAGACTTTGTTG-3' \\
\hline & $\mathrm{R}$ & 5'-GAGGGTAGGCTGGCCTATAGGCT-3' \\
\hline
\end{tabular}

F, forward Primer; R, reverse primer.

\section{Western blotting assay}

RAW 264.7 cells $\left(2 \times 10^{6} / \mathrm{mL}\right)$ were pretreated with SM905 (0, $0.1,1$, and $10 \mu \mathrm{mol} / \mathrm{L})$ for $1 \mathrm{~h}$ and stimulated with $1 \mu \mathrm{g} / \mathrm{mL}$ LPS for $15 \mathrm{~min}$ (MAPKs and IKBa) or $20 \mathrm{~h}$ (iNOS and COX-2). The cells were collected and lysed in SDS sample buffer $(62.5$ $\mathrm{mM}$ Tris- $\mathrm{HCl}$, pH 6.8, 2\% SDS, 10\% glycerol, 5\% 2-mercaptoethanol and $0.02 \%$ bromphenol blue) and boiled for $5 \mathrm{~min}$ at $100{ }^{\circ} \mathrm{C}$. Proteins were resolved by $12 \%$ SDS-polyacrylamide gel electrophoresis (PAGE), transferred to a nitrocellulose membrane (Amersham Pharmacia Biotech, Buckinghamshire, UK) and blocked with 5\% non-fat milk powder-TBST buffer (TBS containing $0.1 \%$ Tween 20 ) for $1 \mathrm{~h}$ at room temperature. The membranes were incubated overnight at $4{ }^{\circ} \mathrm{C}$ with a 1:1000 dilution of one of the polyclonal antibodies against iNOS, COX-2, phospho-ERK, phospho-p38, phospho-JNK, IkBa, and $\beta$-actin. The blots were rinsed three times with TBST buffer for $15 \mathrm{~min}$ each time. The washed blots were incubated with 1:5000 dilution of the horseradish peroxidase conjugated-secondary antibody (Biotechnology Company, Shanghai, China) for $1 \mathrm{~h}$ and then washed three times with the TBST buffer. The transferred proteins were visualized with an enhanced chemiluminescence detection kit (Amersham Pharmacia Biotech, Buckinghamshire, UK).

\section{Determination of NF-KB nuclear translocation}

RAW 264.7 cells $\left(2 \times 10^{6} / \mathrm{mL}\right)$ were pretreated with SM905 (0, $0.1,1$, and $10 \mu \mathrm{mol} / \mathrm{L}$ ) for $1 \mathrm{~h}$ before stimulation with $1 \mu \mathrm{g} / \mathrm{mL}$ LPS for $1 \mathrm{~h}$. The cells were then fixed with $4 \%$ paraformaldehyde for $20 \mathrm{~min}$ and permeabilized with $0.5 \%$ Triton X-100 for 15 min. After $1 \mathrm{~h}$ incubation with blocking buffer (5\% BSA in PBS), cells were incubated with anti-NF-kB/p65 antibody diluted at 1:100 in blocking buffer overnight at $4{ }^{\circ} \mathrm{C}$, washed, and then incubated with FITC-conjugated anti-rabbit IgG diluted at 1:1000 in blocking buffer for $1 \mathrm{~h}$. In order to identify the nucleus, the FITC-conjugated-labeled samples were counterstained with a 1:500 dilution of Hoechst for $2 \mathrm{~min}$. Fluorescent images were observed under the Leica TCS SP2 laser scanning spectral confocal microscope (Leica, Germany).

\section{Statistical analysis}

Data were analyzed using Student's $t$-test and one-way analysis of variance (ANOVA) with Newman-Keuls multiple comparisons on post-tests. Nonparametric data were analyzed using Mann-Whitney $U$ test. $P<0.05$ was considered to be statistically significant.

\section{Results \\ SM905 inhibited LPS-induced NO and pro-inflammatory cytokine TNF- $\alpha$, IL-1 $\beta$, and IL- 6 production}

To investigate the effect of SM905 on NO generation, we measured the accumulation of nitrite, the stable end product of $\mathrm{NO}$, in the culture medium using Griess reagent. As shown in Figure 1, the nitrite production by RAW 264.7 cells was dramatically increased over basal levels after stimulation with LPS for $20 \mathrm{~h}$. Pretreatment with SM905 at 0.1, 1, and 10 $\mu \mathrm{mol} / \mathrm{L}$ significantly inhibited the LPS-induced NO production. Similarly, the LPS-induced production of pro-inflammatory cytokines (TNF-a, IL-1 $\beta$, and IL-6) was also inhibited by SM905. SM905 has been demonstrated to have a low cytotoxicity in our previous study ${ }^{[26]}$. In an MTT assay, we observed that SM905 did not affect the viability of RAW 264.7 cells at a dosage of $10 \mu \mathrm{mol} / \mathrm{L}$ or less (data not shown). Thus, SM905 induced a suppression of LPS-induced macrophage inflammatory response, which was not associated with its cytotoxicity.

\section{SM905 decreased both protein and mRNA expression of iNOS and COX-2}

iNOS and COX-2, two critical enzymes associated with proinflammatory mediator production, were then analyzed by using a Western blotting assay. Figure 2A shows that $20 \mathrm{~h}$ after stimulation with LPS the levels of iNOS and COX-2 proteins were markedly increased in RAW 264.7 cells. Treatment with SM905 inhibited the magnitude of these two molecules in a dose-dependent manner. iNOS is the enzyme responsible for the production of NO by macrophages, which catalyzes the conversion of L-arginine to $\mathrm{NO}$ and L-citrulline ${ }^{[29]}$. The inhibition of the protein expression of iNOS enzyme was concurrent with the reduction of NO secretion in SM905-treated cells, suggesting that the suppressive effect of SM905 on NO production is primarily due to the inhibition of the iNOS expression. 

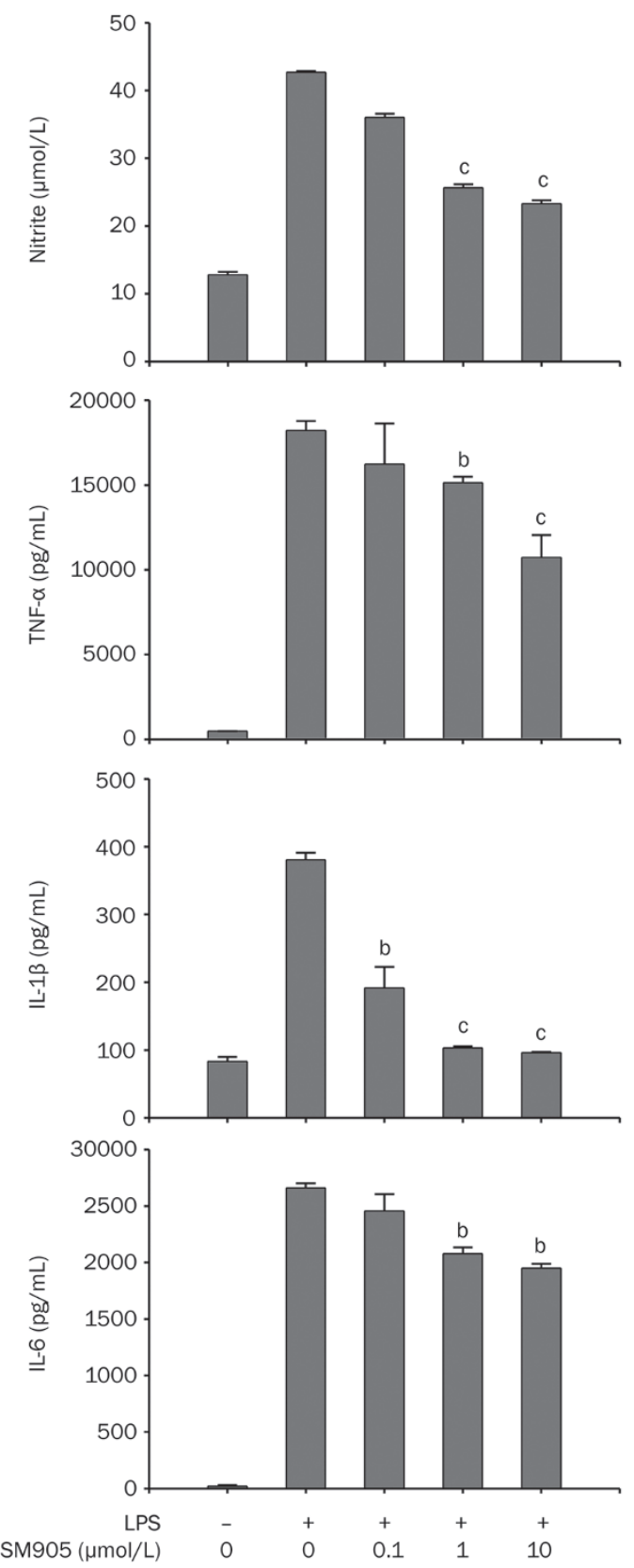

Figure 1. Effect of SM905 on LPS-induced NO, and pro-inflammatory cytokine TNF- $\alpha$, IL-1 $1 \beta$, IL-6 production. RAW 264.7 cells $\left(5 \times 10^{5} / \mathrm{mL}\right)$ were pretreated with the indicated concentrations of SM905 for $1 \mathrm{~h}$ followed by stimulation with LPS for $20 \mathrm{~h}$ in 96-well plates in triplicate. The supernatants were collected and assayed for nitrite generation and TNF- $\alpha$, IL-1 $\beta$, IL- 6 production by using Griess assay and ELISA, respectively. Results presented are mean \pm SEM. $n=3 .{ }^{b} P<0.05,{ }^{c} P<0.01$ vs LPSstimulated but SM905 non-treated control group.

We further determined whether SM905 influenced transcription of iNOS and COX-2 mRNA by using real-time PCR analysis. Figure $2 \mathrm{~B}$ depicts the results of basal and evoked levels of iNOS and COX-2 mRNA with or without SM905 treatment after incubation with LPS for $3 \mathrm{~h}$. Pretreatment with SM905 prominently inhibited the mRNA expression levels of iNOS

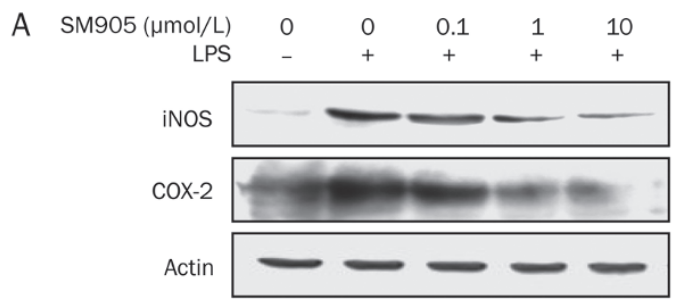

B

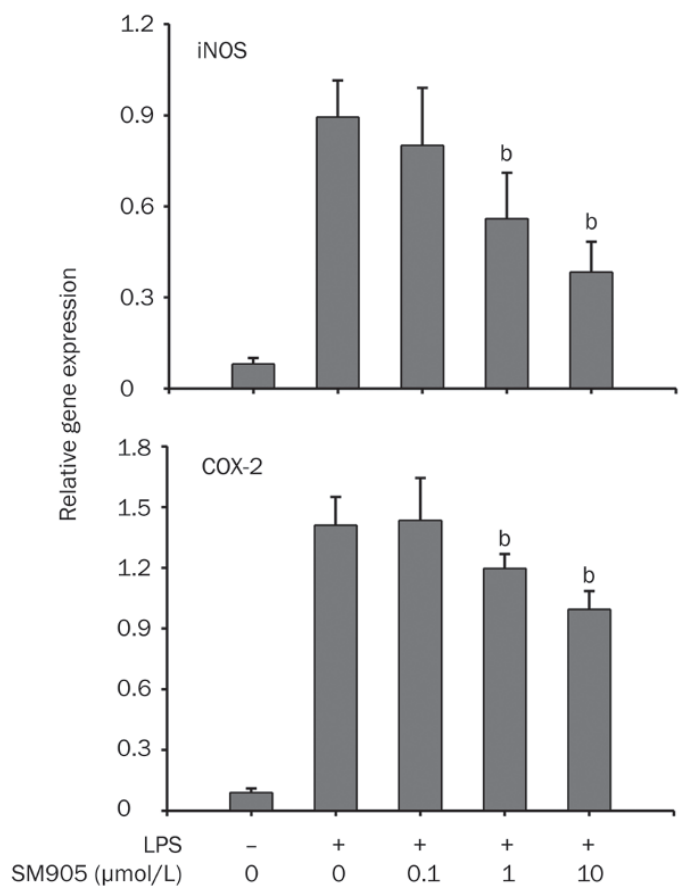

Figure 2. Effect of SM905 on LPS-induced protein and mRNA expression of iNOS and COX-2. (A) RAW 264.7 cells $\left(2 \times 10^{6} / \mathrm{mL}\right)$ were pretreated with the indicated concentrations of SM905 for $1 \mathrm{~h}$ followed by stimulation with LPS $(1 \mu \mathrm{g} / \mathrm{mL})$ for $20 \mathrm{~h}$ and then lysed in SDS sample buffer. The lysates were then probed for iNOS, COX-2 and $\beta$-actin by Western blotting. The results presented are from one experiment, which is representative of two others performed. (B) RAW 264.7 cells $\left(2 \times 10^{6} / \mathrm{mL}\right)$ were pretreated with the indicated concentrations of SM905 for $1 \mathrm{~h}$ followed by stimulation with LPS $(1 \mu \mathrm{g} / \mathrm{mL})$ for $3 \mathrm{~h}$. Total RNA was isolated and analyzed for mRNA expression with real-time PCR. The relative gene expression was obtained after normalization with HPRT. Results are presented as mean \pm SEM of three to four samples. ${ }^{\mathrm{b}} P<0.05,{ }^{\mathrm{c}} P<0.01$ vs LPS-stimulated but $\mathrm{SM} 905$ non-treated control group.

and COX-2. This result suggests that SM905 is able to affect iNOS and COX-2 gene transcription upon RAW 264.7 cell activation.

\section{SM905 did not influence TLR4 and MD-2, but slightly reduced CD14 mRNA expression}

To investigate the possible role of SM905 in the signaling that transmits LPS stimuli into the cell, first the mRNA expression of three members of the LPS receptor complex (CD14, TLR4, and MD-2) was tested. As shown in Figure 3, the mRNA expression of CD14, TLR4, and MD-2 is regulated differently by LPS. LPS stimulation of RAW 264.7 cells for $3 \mathrm{~h}$ caused a 

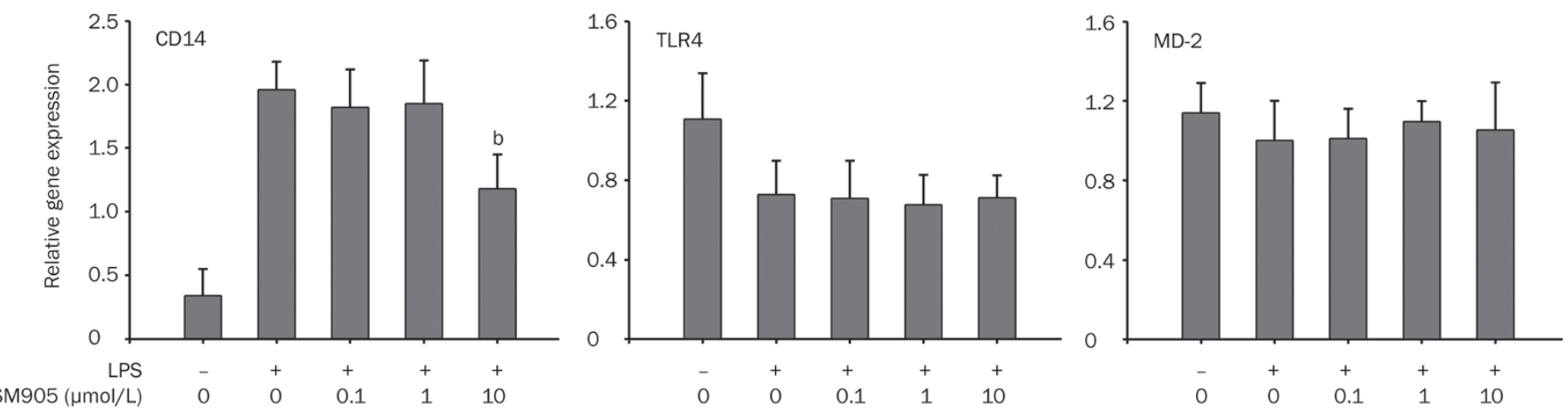

Figure 3. Effect of SM905 on LPS receptor CD14, TLR4 and MD- 2 expression. RAW 264.7 cells $\left(2 \times 10^{6} / \mathrm{mL}\right)$ were pretreated with the indicated concentrations of SM905 for $1 \mathrm{~h}$ followed by stimulation with LPS $(1 \mu \mathrm{g} / \mathrm{mL})$ for $3 \mathrm{~h}$. Total RNA was isolated and analyzed for mRNA expression with real-time PCR. The relative gene expression was obtained after normalization with HPRT. Results are presented as mean \pm SEM. $n=3$. ${ }^{b} P<0.05$ vs $L P S-$ stimulated but SM905 non-treated control group.

relative increase in CD14 mRNA expression. In contrast, there was no evident increase of TLR4 and MD-2 mRNA levels. SM905 did not influence the constitutive expression levels of TLR4 and MD-2 mRNA, but exhibited a statistically effective inhibitory effect on the increased expression of CD14 at 10 $\mu \mathrm{mol} / \mathrm{L}$. Nevertheless, this effect appears not sufficient for the prominent reduction of $\mathrm{NO}$ and pro-inflammatory cytokine secretion in SM905-treated macrophages.

SM905 inhibited LPS-induced phosphorylation of ERK1/2, p38, and JNK, and degradation of IKB

Next, the action of SM905 on intracellular signaling transduction pathways downstream of the LPS receptor was investigated. The MAPK pathway has been well recognized to regulate pro-inflammatory cytokine production ${ }^{[13]}$. We examined the phosphorylation of ERK, p38, and JNK MAPKs in RAW 264.7 cells after LPS stimulation for $15 \mathrm{~min}$. The result showed that the levels of activated ERK, p38, and JNK MAPKs were very low in control cells without LPS stimulation, and LPS activated all three major MAPKs within $15 \mathrm{~min}$. Treatment with SM905 exerted an apparent inhibitory effect on LPS-triggered phosphorylation of ERK, p38, and JNK MAPKs in RAW 264.7 cells (Figure 4A).

The NF-kB pathway regulates the transcription of a wide array of genes, including pro-inflammatory cytokines, iNOS and COX-2 ${ }^{[14]}$. The nuclear translocation of NF-kB depends on the degradation of its inhibitory IкBa protein. Therefore, we tested the effect of SM905 on the levels of IkBa using a Western blotting assay. As shown in Figure 4B, the IkBa protein level decreased markedly within 15 min after LPS stimulation. Pretreatment of cells with SM905 $(0.1,1,10 \mu \mathrm{mol} / \mathrm{L})$ inhibited IкBa degradation in a dose-dependent manner.

In addition to NF-kB pathway, iNOS expression can also be modulated by the IRF pathway. The mRNA expression of IRF-1, STAT1, and IP-10 was very low before LPS stimulation (Figure 4C). Upon exposure to LPS, a remarkable increase in the expression of IRF-1, STAT1, and IP-10 was observed within 3 h. However, treatment with SM905 did not affect the increased expression of these molecules (Figure 4C). These results suggest that the inhibitory effects of SM905 on the LPStriggered inflammatory response are correlated with MAPK and NF-kB pathways, but not the IRF pathway.

\section{SM905 inhibited LPS-induced NF-KB translocation into nucleus}

Once released from IkB, the free NF-kB translocates into the nucleus, where it stimulates target gene transcription. To demonstrate the effect of SM905 on the NF-kB pathway, the nuclear translocation of NF-kB/p65 was viewed under alaser confocal microscope. In a separate series of experiments, RAW 264.7 cells stimulated with LPS showed a dramatic increase in the translocation of NF-KB into the nucleus and its levels reached a peak at $1 \mathrm{~h}$ after stimulation (Figure 5). In contrast, the LPS-induced NF-kB nuclear translocation was markedly impaired after SM905 treatment (Figure 5). This result suggests that SM905 inhibits IkBa degradation, and prevents NF- $\mathrm{kB}$ activation and translocation into the nucleus.

\section{Discussion}

The antimalarial drug artemisinin and its derivatives exhibit potent immunosuppressive activity. It was reported that artemisinin inhibited NF-kB-mediated iNOS expression and $\mathrm{NO}$ synthesis ${ }^{[30]}$. Owing to this property, several artemisinin derivatives were found to be effective for treating experimental arthritis and lupus nephritis in animal models, however, their bioactivity is limited ${ }^{[31-34]}$. SM905 is a novel artemisinin derivative with promising immunosuppressive activity in vitro and in vivo ${ }^{[26]}$, and oral administration of SM905 induced suppression of collagen-induced arthritis in mice ${ }^{[27]}$. The present study provided evidence to demonstrate that SM905 posesses potent anti-inflammatory properties by inhibiting $\mathrm{NO}$ and proinflammatory cytokine secretion in RAW 264.7 macrophages. Furthermore, we, for the first time, systematically analyzed the mechanisms of action of a new artemisinin derivative on LPS signaling, and found it profoundly inhibited the two major signal transduction pathways, those for the MAPKs (ERK, p38, and JNK) and NF-KB, known to be involved in the 

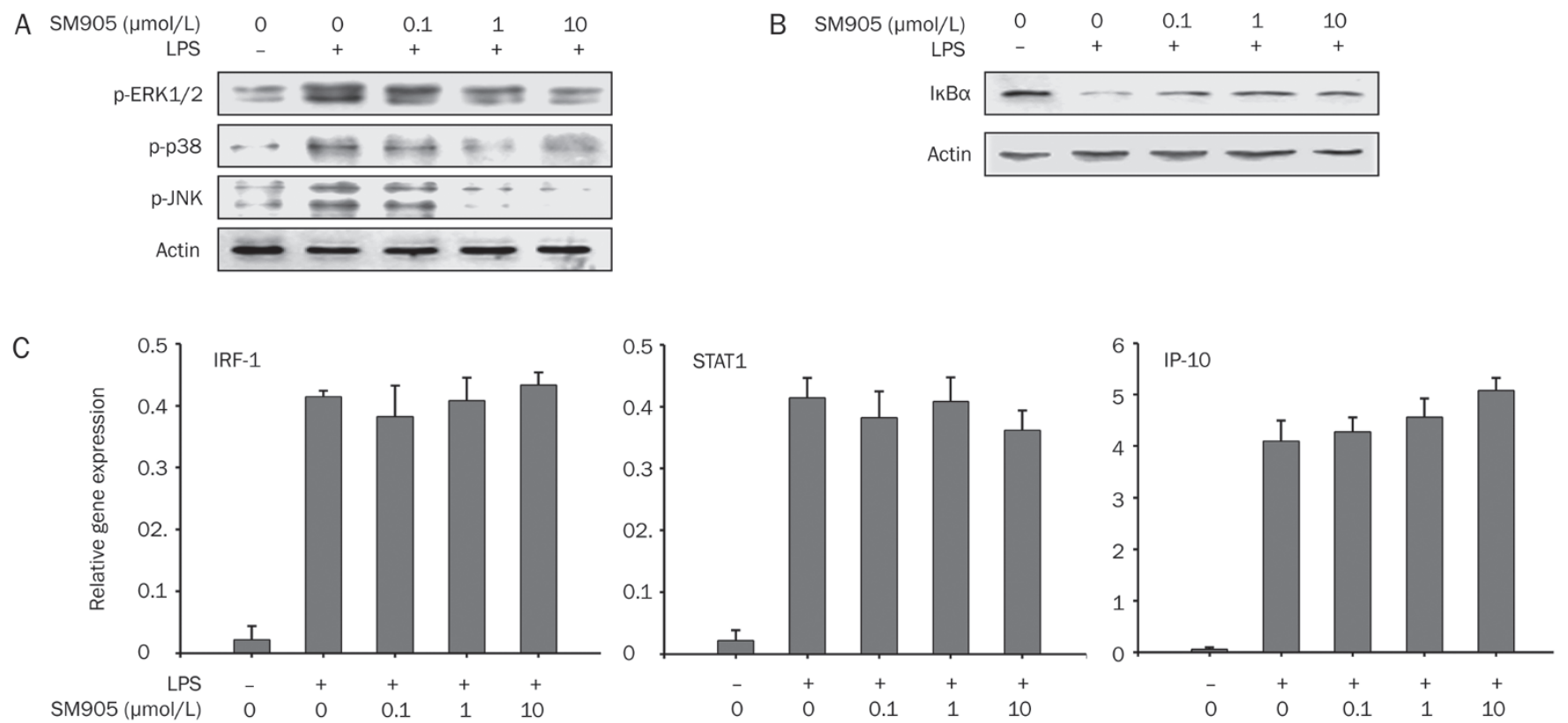

Figure 4. Effect of SM905 on LPS-induced MAPK activation, IkB $\alpha$ degradation and expression of IRF-1, STAT1, and IP-10 mRNA. (A) SM905 inhibited activation of ERK, p38, and JNK MAPKs in LPS-stimulated RAW 264.7 cells. RAW 264.7 cells $\left(2 \times 10^{6}\right.$ cells $\left./ \mathrm{mL}\right)$ were pretreated with the indicated concentrations of SM905 for $1 \mathrm{~h}$ followed by stimulation with LPS $(1 \mu \mathrm{g} / \mathrm{mL})$ for $15 \mathrm{~min}$. Cells were lysed and assayed for phospho-ERK, phospho-p38, and phospho-JNK by Western blotting. The blots were probed with $\beta$-actin antibody to confirm equal protein levels. (B) SM905 inhibited IKB $\alpha$

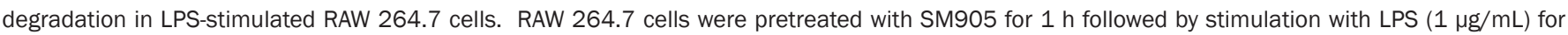
$15 \mathrm{~min}$. Cells were lysed and assayed for IKB $\alpha$ and $\beta$-actin by Western blotting. The results presented are from one experiment, which is representative of two others performed. (C) SM905 had no apparent effect on IRF-1, STAT1, and IP-10 expression. RAW 264.7 cells were pretreated with SM905 for $1 \mathrm{~h}$ followed by stimulation with LPS $(1 \mu \mathrm{g} / \mathrm{mL})$ for $3 \mathrm{~h}$. Total RNA was isolated and analyzed for mRNA expression with real-time PCR. The relative gene expression was obtained after normalization with HPRT. Results were presented as mean \pm SEM, $n=3$.

regulation of inflammatory response.

In LPS signaling, the binding of LPS to its receptor is the first step for the initiation of intracellular signaling cascades, and the expression levels of the LPS receptor are of significance for enabling optimal LPS responsiveness ${ }^{[35,36]}$. RAW 264.7 macrophages constitutively express high levels of TLR4 and MD-2 mRNA, and SM905 did not affect the steady-state expression of these two components. For CD14, LPS induced a prominent increase in its mRNA expression. Treatment with SM905 attenuated the enhanced expression of CD14 in response to LPS, but this effect was limited. Only at the high dosage of $10 \mathrm{\mu mol} / \mathrm{L}$ did SM905 show a moderate inhibitory effect on CD14 expression. Moreover, the downstream IRF pathway was apparently not affected by SM905, which collectively indicats that the components of the LPS receptor complex, CD14, TLR4, and MD-2, may not play a key role in the mechanism of action by which SM905 exerts its prominent inhibitory effect on LPS signaling.

Activation of the ERK, p38, and JNK MAPKs is important in mediating a broad array of cellular responses, such as cell proliferation and differentiation, transcription factor activation, and cytokine gene expression and production ${ }^{[37,38]}$. In this study, we observed that SM905 downregulated the LPStriggered activation of the ERK, p38, and JNK MAPKs in RAW 264.7 macrophages. These findings are consistent with our previous study that artemether inhibited Ras-Raf-ERK activation $^{[21]}$, and the new artemisinin derivative SM905 suppressed the activation of ERK, p38, and JNK MAPKs in T cell receptor (TCR)/CD3-mediated primary T cell activation ${ }^{[26]}$. The activation of all three MAPKs was suppressed by SM905, suggesting that SM905 might influence signaling factors that lie upstream of MAPKs. Among the MAPK family, p38, and JNK in particular have been implicated in the regulation of inflammatory mediators, including the pro-inflammatory cytokines, iNOS, and so on, which make them potential targets for antiinflammatory therapeutics ${ }^{[37]}$. The anti-inflammatory effect of SM905 in RAW 264.7 macrophages may depend primarily on the inhibition of the p38 and JNK MAPK activation.

Much experimental evidence has pointed out the effect of artemisinin derivatives on the NF-KB pathway ${ }^{[32,33,39]}$. It is known that the parent analog artemisinin has the ability to inhibit the activation of the nuclear factor NF- $\mathrm{kB}$, and thereby inhibits NO synthesis in LPS/cytokine mix (IL-1 $\beta$, IFN- $\gamma$, and TNF- $\alpha$ )-stimulated human astrocytoma T67 cells ${ }^{[30]}$. To test the action of SM905 on the NF-kB pathway, we observed two critical events for the activation of this pathway, namely the degradation of IKBa inhibitor proteins and the nuclear translocation of nuclear transcription factor NF-kB/p65. Firstly, pretreatment with SM905 prevented the degradation of IKBa. Then, using immunofluorescence analysis, the inhibitory effect 
LPS
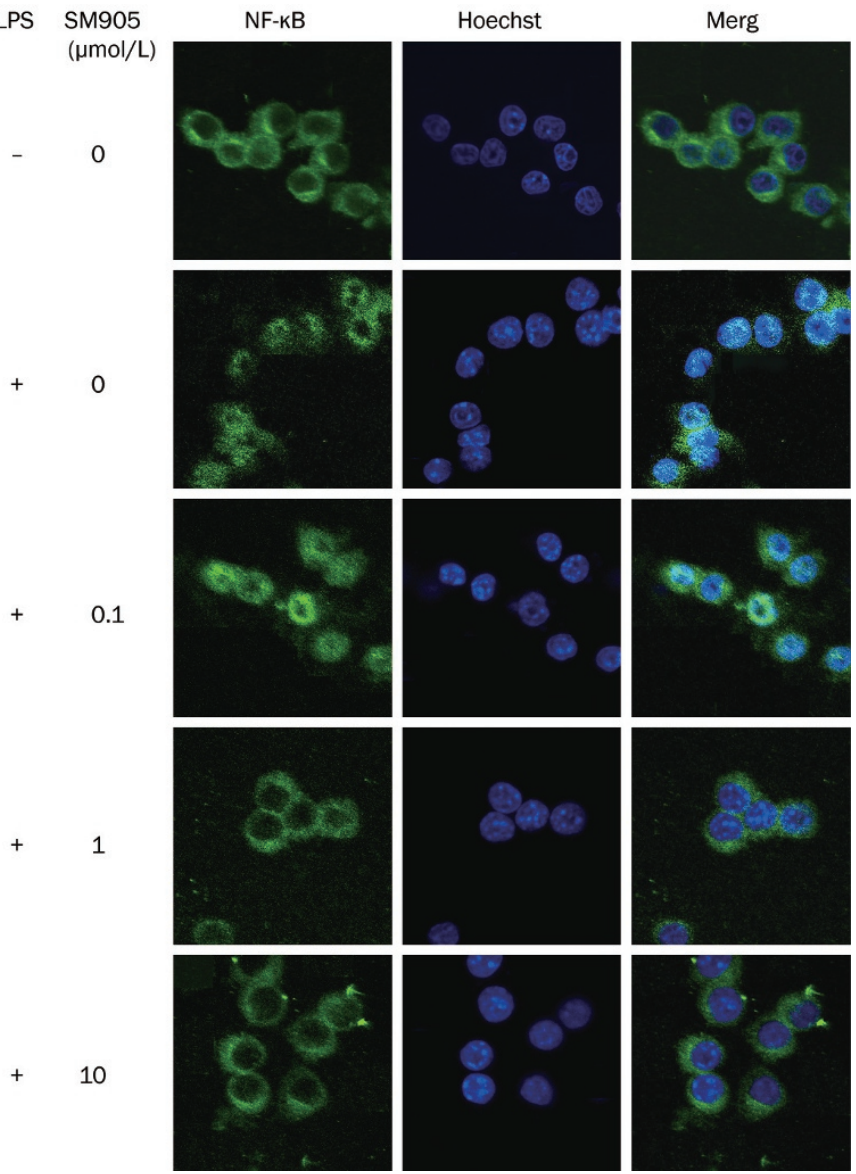

Figure 5. Effect of SM905 on LPS-induced NF-KB translocation into the nucleus. RAW 264.7 cells $\left(2 \times 10^{6}\right.$ cells $\left./ \mathrm{mL}\right)$ were pretreated with the indicated concentrations of SM905 for $1 \mathrm{~h}$ followed by stimulation with LPS $(1 \mu \mathrm{g} / \mathrm{mL})$ for $1 \mathrm{~h}$. Samples were prepared for confocal microscopy analysis. The results shown are from one experiment, which is representative of two others performed.

of SM905 on NF-kB/p65 translocation from cytoplasm into the nucleus was clearly seen. The effective dosages of SM905 for inhibiting the IкBa degradation and NF-kB nuclear translocation were consistent with that for inhibiting MAPKs activation. Since the MAPK pathway can also play a role in the activation of NF-кB, SM905 effectively inhibited NF-кB translocation, which may be partially mediated by inhibiting MAPKs activation.

The IRF pathway can induce iNOS gene expression ${ }^{[15]}$. It has been well recognized that the induction of macrophage gene expression by LPS utilizes both MyD88-dependent signaling cascades, including the MAPK and NF-KB pathways, and MyD88-independent signaling cascades, for example the IRF pathway ${ }^{[10]}$. The MyD88-independent gene expression is predominantly transcriptionally regulated by $\mathrm{LPS}^{[10]}$. Although the IRF-1, STAT1, and IP-10 mRNA expression were strongly induced by LPS, treatment with SM905 showed no significant effect on their gene expression. This result suggests that the inhibitory effect of SM905 on LPS-induced iNOS expression may not be due to the IRF pathway. SM905 seems to have a specific inhibitory action on MyD88-dependent pathway; however, future experiments will be required to test this hypothesis.

In conclusion, the result of this study illustrated the antiinflammatory property of the new artemisinin derivative SM905 by inhibiting NO and pro-inflammatory cytokine production, as well as the iNOS and COX-2 expression in RAW 264.7 cells. These effects were mediated, at least partially, by inhibiting the activation of the MAPK and NF- $\mathrm{kB}$ signal transduction pathways. The novel compound SM905, derived from the natural product artemisinin, may provide an alternative candidate for the safe and effective treatment of chronic inflammatory autoimmune diseases, such as RA and systemic lupus erythematosus.

\section{Acknowledgements}

This work was supported by a grant from Shanghai Science and Technology Committee (№ 06DZ19006) and the Knowledge Innovation Program of the Chinese Academy of Sciences (№ SIMM0709QN-01).

\section{Author contribution}

Jun-Xia WANG, Jian-Ping ZUO designed research; JunXia WANG performed research; Ying LI contributed new Artemisinin derivatives; Jun-Xia WANG, Li-Fei HOU, Yang YANG, Wei TANG , Jian-Ping ZUO analyzed the data; Jun-Xia WANG, Jian-Ping ZUO wrote the paper.

\section{References}

1 Stoy N. Macrophage biology and pathobiology in the evolution of immune responses: a functional analysis. Pathobiology 2001; 69: 179-211.

2 Guha M, Mackman N. LPS induction of gene expression in human monocytes. Cell Signal 2001; 13: 85-94.

3 O'Neill LA. Targeting signal transduction as a strategy to treat inflammatory diseases. Nat Rev Drug Discov 2006; 5: 549-63.

4 Akashi S, Shimazu R, Ogata H, Nagai Y, Takeda K, Kimoto M, et al. Cutting edge: cell surface expression and lipopolysaccharide signaling via the toll-like receptor 4-MD-2 complex on mouse peritoneal macrophages. J Immunol 2000; 164: 3471-5.

5 Lichtman SN, Wang J, Lemasters JJ. LPS receptor CD14 participates in release of TNF-alpha in RAW 264.7 and peritoneal cells but not in kupffer cells. Am J Physiol 1998; 275: G39-46.

6 Medvedev AE, Kopydlowski KM, Vogel SN. Inhibition of ipopolysaccharide-induced signal transduction in endotoxin-tolerized mouse macrophages: dysregulation of cytokine, chemokine, and toll-like receptor 2 and 4 gene expression. J Immunol 2000; 164: 5564-74.

7 Dunne A, O'Neill LA. Adaptor usage and Toll-like receptor signaling specificity. FEBS Lett 2005; 579: 3330-5.

8 Kawai T, Adachi O, Ogawa T, Takeda K, Akira S. Unresponsiveness of MyD88-deficient mice to endotoxin. Immunity 1999; 11: 115-22.

9 Kawai T, Takeuchi O, Fujita T, Inoue J, Muhlradt PF, Sato S, et al. Lipopolysaccharide stimulates the MyD88-independent pathway and results in activation of IFN-regulatory factor 3 and the expression of a subset of lipopolysaccharide-inducible genes. J Immunol 2001; 167 : 5887-94.

10 Bjorkbacka H, Fitzgerald KA, Huet F, Li X, Gregory JA, Lee MA, et al. The induction of macrophage gene expression by LPS predominantly 
utilizes Myd88-independent signaling cascades. Physiol Genomics 2004; 19: 319-30.

11 Kracht M, Saklatvala J. Transcriptional and post-transcriptional control of gene expression in inflammation. Cytokine 2002; 20: 91106.

12 Widmann C, Gibson S, Jarpe MB, Johnson GL. Mitogen-activated protein kinase: conservation of a three-kinase module from yeast to human. Physiol Rev 1999; 79: 143-80.

13 Means TK, Pavlovich RP, Roca D, Vermeulen MW, Fenton MJ. Activation of TNF-alpha transcription utilizes distinct MAP kinase pathways in different macrophage populations. J Leukoc Biol 2000; 67: 88593.

14 Tak PP, Firestein GS. NF-kappaB: a key role in inflammatory diseases. J Clin Invest 2001; 107: 7-11.

15 Kamijo R, Harada H, Matsuyama T, Bosland M, Gerecitano J, Shapiro $D$, et al. Requirement for transcription factor IRF-1 in NO synthase induction in macrophages. Science 1994; 263: 1612-5.

16 Jacobs AT, Ignarro LJ. Lipopolysaccharide-induced expression of interferon-beta mediates the timing of inducible nitric-oxide synthase induction in RAW 264.7 macrophages. J Biol Chem 2001; 276 : 47950-7.

17 Toshchakov V, Jones BW, Perera PY, Thomas K, Cody MJ, Zhang S, et al. TLR4, but not TLR2, mediates IFN-beta-induced STAT1alpha/betadependent gene expression in macrophages. Nat Immunol 2002; 3: 392-8.

18 Ohmori Y, Hamilton TA. Requirement for STAT1 in LPS-induced gene expression in macrophages. J Leukoc Biol 2001; 69: 598-604.

19 Lu L. Study on effect of Cordyceps sinensis and artemisinin in preventing recurrence of lupus nephritis. Zhongguo Zhong Xi Yi Jie He Za Zhi 2002; 22: 169-71. Chinese.

20 Noori S, Naderi GA, Hassan ZM, Habibi Z, Bathaie SZ, Hashemi SM. Immunosuppressive activity of a molecule isolated from Artemisia annua on DTH responses compared with cyclosporin A. Int Immunopharmacol 2004; 4: 1301-6.

21 Wang JX, Tang W, Shi LP, Wan J, Zhou R, Ni J, et al. Investigation of the immunosuppressive activity of artemether on T-cell activation and proliferation. Br J Pharmacol 2007; 150: 652-61.

22 Zhou WL, Wu JM, Wu QL, Wang JX, Zhou Y, Zhou R, et al. A novel artemisinin derivative, 3-(12-beta-artemisininoxy) phenoxyl succinic acid (SM735), mediates immunosuppressive effects in vitro and in vivo. Acta Pharmacol Sin 2005; 26: 1352-8.

23 Yang ZS, Wang JX, Zhou Y, Zuo JP, Li Y. Synthesis and immunosuppressive activity of new artemisinin derivatives. Part 2: 2-[12(beta or alpha)-dihydroartemisinoxymethyl(or 1'-ethyl)]phenoxyl propionic acids and esters. Bioorg Med Chem 2006; 14: 8043-9.

24 Yang ZS, Zhou WL, Sui Y, Wang JX, Wu JM, Zhou Y, et al. Synthesis and immunosuppressive activity of new artemisinin derivatives. 1. [12(beta or alpha)-Dihydroartemisininoxy]phen(ox)yl aliphatic acids and esters. J Med Chem 2005; 48: 4608-17.

25 Zhang JX, Wang JX, Zhang Y, Zuo JP, Wu JM, Sui Y, et al. Synthesis and immunosuppressive activity of new artemisinin derivatives contain- ing polyethylene glycol group. Yao Xue Xue Bao 2006; 41: 65-70. Chinese.

26 Wang JX, Tang W, Yang ZS, Wan J, Shi LP, Zhang Y, et al. Suppressive effect of a novel water-soluble artemisinin derivative SM905 on T cell activation and proliferation in vitro and in vivo. Eur J Pharmacol 2007; 564: 211-8.

27 Wang JX, Tang W, Zhou R, Wan J, Shi LP, Zhang Y, et al. The new water-soluble artemisinin derivative SM905 ameliorates collageninduced arthritis by suppression of inflammatory and Th17 responses. Br J Pharmacol 2008; 153: 1303-10.

28 Zhou R, Zheng SX, Tang W, He PL, Li XY, Yang YF, et al. Inhibition of inducible nitric-oxide synthase expression by (5R)-5-hydroxytriptolide in interferon-gamma- and bacterial lipopolysaccharide-stimulated macrophages. J Pharmacol Exp Ther 2006; 316: 121-8.

29 Nathan C, Xie QW. Regulation of biosynthesis of nitric oxide. J Biol Chem 1994; 269: 13725-8.

30 Aldieri E, Atragene D, Bergandi L, Riganti C, Costamagna C, Bosia A, et al. Artemisinin inhibits inducible nitric oxide synthase and nuclear factor NF-kB activation. FEBS Lett 2003; 552: 141-4.

31 Cuzzocrea S, Saadat F, Di Paola R, Mirshafiey A. Artemether: a new therapeutic strategy in experimental rheumatoid arthritis. Immunopharmacol Immunotoxicol 2005; 27: 615-30.

32 Dong YJ, Li WD, Tu YY. Effect of dihydro-qinghaosu on auto-antibody production, TNF alpha secretion and pathologic change of lupus nephritis in BXSB mice. Zhongguo Zhong Xi Yi Jie He Za Zhi 2003; 23 : 676-9. Chinese.

33 Li WD, Dong YJ, Tu YY, Lin ZB. Dihydroarteannuin ameliorates lupus symptom of BXSB mice by inhibiting production of TNF-alpha and blocking the signaling pathway NF-kappa B translocation. Int Immunopharmacol 2006; 6: 1243-50.

34 Mirshafiey A, Saadat F, Attar M, Di Paola R, Sedaghat R, Cuzzocrea S. Design of a new line in treatment of experimental rheumatoid arthritis by artesunate. Immunopharmacol Immunotoxicol 2006; 28 : 397-410.

35 Means TK, Lien E, Yoshimura A, Wang S, Golenbock DT, Fenton MJ. The CD14 ligands lipoarabinomannan and lipopolysaccharide differ in their requirement for Toll-like receptors. J Immunol 1999; 163: 6748-55.

36 Qureshi ST, Lariviere L, Leveque G, Clermont S, Moore KJ, Gros P, et al. Endotoxin-tolerant mice have mutations in Toll-like receptor 4 (TIr4). J Exp Med 1999; 189: 615-25.

37 Johnson GL, Lapadat R. Mitogen-activated protein kinase pathways mediated by ERK, JNK, and p38 protein kinases. Science 2002; 298: 1911-2.

38 Su B, Karin M. Mitogen-activated protein kinase cascades and regulation of gene expression. Curr Opin Immunol 1996; 8: 402-11.

39 Lee HG, Kim H, Oh WK, Yu KA, Choe YK, Ahn JS, et al. Tetramethoxy hydroxyflavone p7F downregulates inflammatory mediators via the inhibition of nuclear factor kappaB. Ann N Y Acad Sci 2004; 1030: 555-68. 